\title{
Intimal Arteritis Assessment
}

National Cancer Institute

\section{Source}

National Cancer Institute. Intimal Arteritis Assessment. NCI Thesaurus. Code C135467.

An evaluation of the presence or degree of intimal arteritis present in a sample. 